\title{
La fundación del Juzgado Privativo de Tierras y Aguas de la Real Audiencia de México, 1692-1735
}

por

\author{
Sergio Eduardo Carrera Quezada ${ }^{1}$ \\ El Colegio de México
}

\begin{abstract}
El presente texto aborda el conjunto de disposiciones jurídicas promulgadas por los monarcas españoles que impulsaron la fundación de instancias gubernamentales comisionadas para la regularización de la propiedad agraria en la América colonial a finales del siglo XVII y comienzos del XVIII. Se dan a conocer los decretos y edictos de los ministros del Juzgado Privativo de Tierras de la Real Audiencia de México para analizar la operatividad de esta dependencia y de las actividades de sus comisionados en las jurisdicciones novohispanas. Asimismo, se subraya la importancia de las composiciones de tierras y ventas de baldios en la historia rural de México, dado que fueron procedimientos que, por un lado, apuntalaron el derecho a la propiedad absoluta, y por el otro, incidieron en la propiedad comunal de los pueblos de indios y en su configuración territorial.
\end{abstract}

Palabras Clave: regularización agraria; Juzgado Privativo de Tierras; Nueva España; composiciones de tierras.

Cómo citar este artículo / Citation: Carrera Quezada, Sergio Eduardo, "La fundación del Juzgado Privativo de Tierras y Aguas de la Real Audiencia de México, 1692-1735", Revista de Indias, LXXIX/276 (Madrid, 2019): 369-398. https://doi.org/10.3989/revindias.2019.011.

\section{INTRODUCCIÓN}

Uno de los principales problemas en la conquista del Nuevo Mundo fue la apropiación irregular de las tierras y sus recursos. En su intento por encontrar una solución y al mismo tiempo obtener beneficios económicos, desde finales del siglo XVI la Corona española comenzó a diseñar una política

\footnotetext{
1 secarrera@colmex.mx, ORCID iD: https://orcid.org/0000-0003-2047-2390.
} 
agraria articulada al régimen fiscal, cuya base de la recaudación provino de la venta de los baldíos y la regularización de las propiedades rurales sin títulos o con demasías ${ }^{2}$. El argumento central era la urgente necesidad de la Real Hacienda para solventar los gastos militares y la defensa de los territorios españoles. Debido a los retrasos en la cobranza de este rubro entre los colonos de las Indias, Carlos II ordenó en 1692 la creación de la Superintendencia del Beneficio y Composición de Tierras, dependencia gubernamental encargada de implementar y vigilar los mecanismos de recaudación en todos los dominios hispanos ${ }^{3}$. En este artículo se abordarán las leyes que dieron origen a esta instancia y a los Juzgados Privativos de Tierras en cada una de las Audiencias. Al tomar como ejemplo la normatividad diseñada para el Juzgado Privativo de Tierras de la Real Audiencia de México, se busca mostrar cómo se desempeñaron sus funcionarios para instrumentar los procedimientos de medición, deslinde y tasación de las propiedades rurales en las provincias de la Nueva España. Estos mecanismos debían ejecutarse de manera expresa y sistemática para agilizar la cobranza a favor del fisco.

La mayoría de los interesados en la historia agraria de México hemos consultado el Cedulario de Tierras editado por Francisco de Solano como un instrumento de referencia documental, aún con los errores de transcripción que contiene ${ }^{4}$. A pesar de ser una fuente imprescindible sobre las leyes agrarias del periodo colonial, muy pocos se han detenido a examinar la propuesta de su compilador. En el apartado introductorio, Francisco de Solano subrayó la importancia de los juzgados y jueces privativos de tierras como piezas clave para la maduración de la política agraria española, en especial para poner en funcionamiento el programa de composiciones y venta de baldíos a lo largo del siglo XVIII, señalamiento que esbozó en trabajos previos ${ }^{5}$. Por dichas razones, en el presente ensayo se analizarán las disposiciones generadas en el seno del Juzgado Privativo de Tierras de México, porque creemos que es importante dar a conocer los edictos y decretos de los jueces privativos de tierras que, hasta donde sabemos, no han sido publicados. La relevancia de estos edictos radica en que contienen las instrucciones giradas a los jueces de comisión y a las justicias locales para la regularización de las propiedades en las provincias novohispanas. Las actividades de estos funcionarios culminaron en la remisión de autos, pareceres, informes, mapas y catastros de las propiedades particulares y de los pueblos de indios en cada una de las alcal-

\footnotetext{
2 Assadourian, 1989. Peset y Menegus, 1994.

3 Torales, 2005: 63.

4 Solano, 1984.

5 Solano, 1977; 1980.
} 
días mayores a la escribanía del juzgado. Allí se comenzó a conformar un acervo documental que, a la postre, es el precedente del ramo Tierras del Archivo General de la Nación de México.

El corpus documental producido por las composiciones ofrece una amplia gama de posibilidades de estudio para las distintas líneas de la disciplina histórica. Dentro de la esfera económica y jurídica se puede abordar la aplicación de las políticas de la Corona española y las respuestas de los grupos sociales en los ámbitos locales. Por la naturaleza de su contenido, esta documentación es imprescindible para la historia agraria, la geografía histórica y la historia ambiental porque contiene valiosas descripciones de los paisajes y las representaciones del espacio que quedaron registradas en las vistas de ojos y las demarcaciones de las tierras. Además, su importancia no queda restringida al periodo colonial, pues la regularización agraria repercutió en la configuración espacial de los pueblos durante el siglo XIX y en el México moderno. Dicha política implicó la ratificación de títulos de propiedad y al mismo tiempo el otorgamiento de nuevos títulos, especialmente entre los poseedores de tierras que la Corona consideraba con dominios imperfectos o irregulares. Así, los despachos de composiciones que recibieron los pueblos de indios se incorporaron al conjunto de títulos legítimos validados por el derecho agrario mexicano. Por esta razón, las autoridades de muchos pueblos presentaron títulos de composiciones en litigios por sus tierras y también para defenderlas frente a las políticas liberales de enajenación y desamortización. La búsqueda de esta documentación por parte de las autoridades de los pueblos fue constante a lo largo del siglo XIX y continuó con la Reforma Agraria posrrevolucionaria en las primeras décadas del siglo XX, pues, con base en el artículo 27 de la Constitución de 1917, la presentación de títulos de propiedad era un requisito tanto para el procedimiento de Reconocimiento, Titulación y Confirmación de Bienes Comunales como para el trámite de Restitución de tierras ${ }^{6}$. Sin embargo, conviene apuntar la distinción entre los títulos de composición de los pueblos y los títulos primordiales, pues aunque ambos hacen referencia a la posesión inmemorial, los primeros fueron elaborados y emitidos por las autoridades virreinales y los oficiales del Juzgado Privativo de Tierras y Aguas, mientras que a los segundos se les atribuye una manufactura eminentemente indígena?

Desde que salió a la luz la magna obra de François Chevalier el asunto de las composiciones de tierras ocupó un lugar destacado en la historiografía

6 Embriz y Ruiz, 1998: 143-143, 155-156.

7 La bibliografía sobre los títulos primordiales es vasta. Véase, por ejemplo, Noguez y Wood, 1998. Menegus, 1999. López, 2003. Ruiz, 2010. 
mexicanista, pues fueron caracterizadas como el principal medio que permitió el despojo de tierras indígenas, su traspaso y legalización a manos de los españoles ${ }^{8}$. Muchos historiadores continuaron - y continúan - reproduciendo esta interpretación, sin advertir que Chevalier se refirió únicamente a las composiciones generales ejecutadas durante los gobiernos de los virreyes don Rodrigo Pacheco de Osorio, don Lope Díez de Aux de Armendáriz y don García Sarmiento de Sotomayor, entre 1635 y 1645 específicamente9. Estudios recientes ayudan a matizar esta anquilosada idea porque muestran que las composiciones realizadas a lo largo del siglo XVIII tuvieron resultados muy distintos que correspondieron a los contextos particulares de cada provincia y región: condiciones geográficas y medioambientales, relaciones sociales, composición sociodemográfica, estructuras agrarias y desarrollo de los derechos de propiedad, entre otros factores ${ }^{10}$.

Con respecto a cómo la regularización agraria comenzó a contribuir a los fondos de la Real Hacienda, Carlos Sempat Assadourian apuntó que en el virreinato del Perú, al poco tiempo de haberse emitido las reales cédulas del primero de noviembre de 1591, las composiciones y venta de baldíos se lograron ejecutar con resultados muy favorables ${ }^{11}$. En 1592 fueron cobrados 188,575 pesos de plata ensayada en el partido de la villa de Trujillo en la provincia de Charcas, mientras que en la ciudad de La Plata y en los corregimientos de Cochabamba, Mizque, Pocona, Chayanta, Yamparaes, los asientos de Porco y Potosí, las villas de Tomina y Tarija se recaudaron 95.145 pesos entre 1594 y $1596^{12}$. En un interesante artículo sobre las quejas de los caciques andinos frente a las composiciones y venta de baldíos a los españoles, Luis Miguel Glave anotó que en la jurisdicción de la Real Audiencia de Lima se pudieron haber colectado cerca de 600.000 pesos entre 1639 y $1648^{13}$. Los españoles de la ciudad de Quito ofrecieron un pago global de 40.000 pesos por los derechos de composición de sus propiedades rurales en 169514. En contraste, para la Nueva España, Francisco de Solano registró el primer cobro por el concepto de composiciones en 1598 por el monto de 7.935 pesos, suma considerablemente inferior en comparación con el virreinato peruano en ese mismo periodo ${ }^{15}$.

\footnotetext{
8 Chevalier, 1956.

9 Wobeser, 1989. Florescano, 1990. Jalpa Flores, 2008.

10 Torales, 2005. Carrera, 2015a. Menegus, 2017.

11 Assadourian, 1989.

12 Jurado, 2014: 25-26.

13 Glave, 2008: 93.

14 Borchart de Moreno, 1980: 125.

15 Solano, 1984: 49.
} 
En los últimos años ha crecido el interés por el tema de la regularización agraria y las composiciones, tanto entre los historiadores mexicanos ${ }^{16}$, como en investigadores de otros países latinoamericanos ${ }^{17}$. No obstante, todavía no se ha hecho un esfuerzo por articular y comparar los resultados de las investigaciones regionales. Aunque laborioso en extremo, este ejercicio sería bastante provechoso para contar con una visión del conjunto y tener un panorama más amplio sobre los resultados concretos de la regularización agraria en la América colonial. Este artículo es el primer paso de una propuesta que tenemos proyectada desarrollar muy pronto.

\section{DEL PROYECTO A LOS PRIMEROS ENSAYOS}

En otros trabajos hemos propuesto que el programa de regularización agraria se llevó a cabo en el marco de las transformaciones en los derechos de acceso a la tierra, los cuales poco a poco se fueron despojando de las características feudales. La entrega de títulos - primero de mercedes no onerosas y después por medio de composiciones - fue coadyuvante para que el dominio absoluto, es decir, la propiedad perfecta, tomara preeminencia jurídica sobre los demás derechos agrarios, porque se suponía que debía ser la base del desarrollo económico de los propietarios. En este sentido, el proyecto para ejecutar las composiciones tuvo como objetivo incrementar las arcas de la Real Hacienda, pero, sobre todo, uniformar las posesiones imperfectas en propiedades absolutas y transformar a sus poseedores en legítimos propie$\operatorname{tarios}^{18}$.

Para tener un mayor conocimiento de la conversión de los distintos derechos agrarios a la propiedad absoluta, conviene señalar algunos antecedentes. La Corona recompensó a los conquistadores de las Indias con mercedes de tierra, de la misma forma que lo había hecho con quienes contribuyeron con la expulsión de los musulmanes y la recuperación del territorio de Castilla. Los herederos de los conquistadores y los nuevos colonos en el Nuevo Mundo también solicitaron mercedes a los cabildos de las villas y ciudades. Sin embargo, los primeros títulos otorgados para la fundación de estancias de ganado únicamente concedían el derecho de pastaje y la construcción de corrales, abrevaderos y otras mejoras a los sitios. Para gozar del derecho pleno

16 Jiménez Gómez, 2003. Torre Ruiz, 2012. López Castillo, 2014. Carrera, 2015b. Goyas, 2015. Mendoza, 2015.

17 Glave, 2008. Balboa y Cabrera, 2008. Sánchez Mejía, 2012. Jurado, 2014.

18 Carrera, 2018. 
a la tierra tanto para uso agrícola como ganadero, el beneficiario de la merced debía cumplir con ciertos requisitos. Primero, no debía vender o donar sus derechos a monasterio o corporación eclesiástica, a fin de evitar el traspaso del espacio al régimen de «manos muertas». También quedaba obligado a realizar las actividades exclusivamente para las cuales había sido destinada la tierra solicitada. Además, tenía que permanecer en ella y según el caso hacerla producir mediante la labranza o poblándola con ganado por lo menos durante cuatro o cinco años ininterrumpidos, antes de vender, donar o transferir sus derechos a otra persona. Le correspondía solicitar la confirmación del rey para que la merced tuviera valor legal, aunque este requerimiento fue revocado en distintas ocasiones debido a la falta de consenso acerca de la instancia facultada para promulgarla. Por último, el sitio de estancia o tierra de labor no debía afectar a otros propietarios ni a las tierras de los indios. Al finalizar el siglo XVI, las mercedes incluían una cláusula que advertía la expropiación de la tierra concedida en caso de que interfiriera con las congregaciones de los indios o la fundación de villas de españoles.

Sumado al hecho de que estos requerimientos no siempre eran cumplidos por los beneficiarios de mercedes, a lo largo del siglo XVI el gobierno novohispano no logró (o no quiso) tomar acciones contra los ocupantes ilegítimos y permitió la usurpación de tierras en detrimento de las tierras de los pueblos, ciudades y villas. La concesión de títulos y la ocupación del suelo se realizaron sin mayor cuidado, como lo admitió el virrey Martín Enríquez de Almansa en $1571^{19}$. Ni siquiera las Ordenanzas de descubrimiento, nueva población y pacificación de las Indias de 1573 pudieron remediar esta situación, pues la distribución de las estancias ganaderas y las tierras de cultivos europeos se continuaron otorgando mediante mercedes no onerosas, de forma dispersa conforme los solicitantes las requerían y dejando amplias extensiones de terrenos incultos. La caída demográfica de los naturales y el inacabado programa de congregaciones fueron factores que incidieron en la venta de tierras indígenas a favor de los españoles, sin que hubiera de por medio un título reconocido por autoridad competente, a pesar de las restricciones expedidas al respecto ${ }^{20}$. Por esta razón, en 1581 el Consejo de Indias le solicitó al virrey Lorenzo Suárez de Mendoza, Conde de Coruña, un reporte de las tierras baldías en la Nueva España para saber si era prudente ordenar su venta mediante subasta pública y calcular cuánto podrían contribuir los ocupantes irregulares por el pago de composiciones ${ }^{21}$. El virrey respondió que informaría

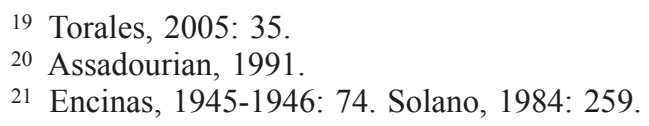


sobre el particular «porque es negocio que ha menester tiempo para mirarlo y dar cuenta de él como conviene» ${ }^{22}$. Y aunque desconocemos su informe, el Conde de Coruña debió de haber advertido la preocupación de los labriegos y ganaderos novohispanos frente a la intención de la Corona por subastar las tierras que ocupaban, porque la real cédula de 8 de mayo de 1589 ordenó a su sucesor, el virrey Álvaro Manrique de Zúñiga, que «no conviene hacer novedad con los poseedores de dichas tierras», aunque previno que la imposición de un gravamen debía ser aplicado a los que no presentaren títulos otorgados por autoridad competente ${ }^{23}$.

El déficit causado por los gastos en las guerras contra los reinos europeos y la búsqueda de una solución al acoso de los piratas a las flotas españolas en la carrera a las Indias, fueron los motivos que animaron a Felipe II para imponer un gravamen a las regalías de la Corona. Además de la aplicación de impuestos a doce arbitrios, el rey ordenó iniciar el cobro por derechos a la posesión y concesión de tierras realengas ${ }^{24}$. El primero de noviembre de 1591 fueron despachadas las reales cédulas con las que el monarca dio un giro a su política agraria ${ }^{25}$. En una de ellas anunció el cobro de ciertos derechos realengos que hasta entonces se había reservado, como el otorgamiento gracioso de mercedes de tierras, al mismo tiempo que admitió «alguna cómoda composición» a quien no lograra manifestar sus títulos o excediera sus límites $^{26}$. La siguiente refrendó el dominio eminente del trono ibérico sobre las Indias y su derecho a la sucesión del señorío americano, por lo que exigió la restitución al Real Patrimonio de las tierras que presentasen situaciones irregulares, pero reservando los bienes comunes para las villas y ciudades, así como las tierras repartidas y confirmadas a los naturales que viviesen en pueblos congregados, con el propósito de «desembarazar la demás tierra para hacer dotación de ella por vía de merced y disponer de ella a mi voluntad» ${ }^{27}$. En la otra real cédula el soberano afirmó que en lo sucesivo las concesiones de tierras realengas debían realizarse mediante subasta pública y otorgó fa-

22 Carta del virrey, Lorenzo Suárez de Mendoza, Conde de Coruña, 28 de octubre de 1582, Archivo General de Indias, Sevilla (AGI), México, 20, n. ${ }^{\circ}$ 92, 1582, f. 8.

23 Solano, 1984: 265.

24 Peset y Menegus, 1994: 584.

25 Solano (1984: 43-44) indica cuatro reales cédulas despachadas el primero de noviembre de 1591 en El Pardo, mientras que Torales (2005: 40-41) registra una más, dirigida a la alta jerarquía eclesiástica.

26 Solano, 1984: 269-272.

27 Real cédula inserta en el documento Traslado de las composiciones de tierras de los vecinos de los pueblos de Huayacocotla y Chicontepec, 1643, 1692, Archivo General de la Nación, México (AGN), Tierras, vol. 3519, exp. 9, fs. 2-2v. Solano, 1984: 273-274. 
cultades a los virreyes para poner en marcha la nueva política de tierras a través del requerimiento de títulos a los poseedores, con suficiente autoridad para admitir pagos de composiciones y entregar nuevos títulos de propiedad ${ }^{28}$.

Al principio los naturales fueron eximidos de cumplir con el programa de regularización agraria, toda vez que la Corona reconocía su derecho al dominio útil de las tierras que poseían y donde producían el tributo. El derecho indiano se nutrió con la incorporación de leyes y costumbres nativas, siempre y cuando no contravinieran la fe católica ni las leyes de Castilla. Por esta razón, las disposiciones relativas a las demarcaciones de los términos de los pueblos y al derecho de los indios a la posesión de sus tierras desde tiempo inmemorial fueron elementos fundamentales en el desarrollo de este marco jurídico ${ }^{29}$. Sin embargo, se debe apuntar que las reales cédulas de 1591 no advirtieron sobre los posibles efectos de la regularización de las propiedades de españoles en las tierras y términos de los pueblos, sino que únicamente señalaron que primero debían concluirse las congregaciones para luego regularizar los sitios y subastar los baldíos. Y aunque los colonos no tenían permitido componer tierras que anteriormente hubiesen pertenecido a indios, en la mayoría de los casos dicha condición pasó por alto gracias al solapamiento de las autoridades virreinales. Fue necesaria otra real cédula que ordenó a los españoles desocupar sus sitios solo en caso de que las tierras fueran útiles para los indígenas, por lo cual el virrey y los presidentes de audiencias proveerían la reubicación de las estancias o «dándoles justa recompensa» a sus dueños ${ }^{30}$.

El primer obstáculo para poner en marcha la nueva política agraria fue la renuencia de los colonos novohispanos, quienes comunicaron su preocupación al virrey Luis de Velasco y le suplicaron que intercediera por ellos frente a su majestad. El virrey Velasco respondió a Felipe II que las condiciones económicas del reino no eran propicias para imponer gravámenes a las estancias ganaderas. Justificó que la ocupación ilegítima de las tierras se debía a la necesidad de los colonos por encontrar medios de sustento, por lo que le parecía que los costos de las diligencias de composiciones afectarían la economía de los labradores y estancieros ${ }^{31}$. Con todo, frente a la presión de la

28 Real cédula inserta en el documento arriba citado, AGN, Tierras, vol. 3519, exp. 9, fs. $2 \mathrm{v}-3 \mathrm{v}$.

29 Menegus, 1992. Pérez, 2009.

${ }^{30}$ Que las tierras sin título que perjudicaren a los indios se desocupen, y si se pusiere pleito se siga, Felipe II, Madrid, 20 de octubre de 1595, editado en León Pinelo, 1992, vol. 3: 2068.

31 Cartas de Luis de Velasco, el mozo, 25 de febrero de 1593, AGI, México, 22, n. ${ }^{\circ} 112$, fs. 2, 3-3v. 
Corona, el virrey Velasco no pudo hacer mucho y se vio forzado a designar al oidor Antonio Maldonado como fiscal especial para ejecutar las composiciones en enero de $1595^{32}$. Sin embargo, cuando don Gaspar de Zúñiga y Acevedo, Conde de Monterrey, sustituyó a Luis de Velasco como virrey de la Nueva España, le informó al monarca que «el licenciado Maldonado no ha hecho cosa alguna, antes ni después de mi venida, ni el virrey», así que se comprometió a hacer tasa y cobranza de las tierras que en adelante se solicitaran y confirmaran ${ }^{33}$.

En 1598 la Real Caja recibió 7,935 pesos por composiciones individuales. Sin embargo, la tibia actitud del gobierno virreinal fue uno de los principales factores que impidieron la venta de tierras consideradas baldías. Incluso, en el último lustro del siglo XVI el gobierno virreinal no sólo continuó otorgando mercedes de manera gratuita, sino además concedió la mayor cantidad de sitios de estancias y caballerías de tierras registrada hasta entonces ${ }^{34}$. $\mathrm{Y}$ es que las autoridades tenían un impedimento: no se habían concluido las congregaciones de los pueblos y por lo tanto estaba pendiente la definición de los espacios que pudieran considerarse como baldíos.

El primer gravamen a las mercedes de tierras fue impuesto por el Conde de Monterrey el 9 de marzo de 1601, cuando ordenó el cobro del valor de la cuarta parte de los terrenos requeridos ${ }^{35}$. Es importante referirnos a estos títulos onerosos porque representaron una innovación jurídica propiamente novohispana, y aunque su número fue reducido, en conjunto muestran los primeros esfuerzos de las autoridades virreinales por instrumentar la venta de bienes realengos. El 27 de mayo de 1605 el virrey Juan de Mendoza y Luna, Marqués de Montesclaros, informó al rey que el cobro de derechos realengos había sido de 5,273 pesos desglosados de la siguiente manera: 1,445 pesos por las composiciones de 31 sitios de estancias y un herido de molino para pan, 2,280 pesos por 65 caballerías de tierra de labor, 485 pesos por el cobro del gravamen al valor de la cuarta parte de 23 sitios de estancias y 1.063 pesos de 62 caballerías. Notificó que faltaban por tasar 206 sitios de estancia, 401 y media caballerías, 27 heridos de molinos y sitios de venta y cuatro fs. $1-1 \mathrm{v}$.

32 Carta del virrey Luis de Velasco, el mozo, 14 de abril de 1595, AGI, México, 23, n. ${ }^{\circ}$ 15,

33 Carta del virrey Conde de Monterrey, 21 de junio de 1595, AGI, México, 23, n. ${ }^{\circ} 85$, 1595 , fs. $2 \mathrm{v}-3$.

34 Prem, 1988.

35 Ordenanza para que por vía de composición se cobre la cuarta parte de lo que hubiere averiguado que valen las tierras y estancias y demás cosas de que se hiciere merced, 9 de marzo de 1601, AGN, Mercedes, vol. 24, fs. 38-38v. Chevalier, 1956: 382. Prem, 1988: 122. 
solares (dos de ellos con remanente de agua). Por desgracia, el informe no incluye datos sobre la localización de las tierras ni de las personas a las que se les cobró este ramo hacendario ${ }^{36}$. Y aunque la década de 1610 registró el mayor número de mercedes adquiridas por el pago de una cuarta parte, la recaudación de este arbitrio en la Nueva España fue notablemente inferior con respecto a lo que la Real Hacienda percibió por el mismo rubro en otras audiencias de la América colonial.

La Corona evaluó el programa de regularización a través de la real cédula del 26 de abril de 1618, las instrucciones que recibió en 1624 el virrey Rodrigo Pacheco de Osorio, Marqués de Cerralvo, y la real cédula del 27 de mayo de $1631^{37}$. En respuesta a estas órdenes, el virrey facultó al oidor Juan González Peñafiel para la ejecución de las diligencias en el partido de Izúcar, donde se pretendía el cobro de 90.000 pesos entre los labradores, que lógicamente se negaron a pagar e hicieron llegar su inconformidad a las instancias más elevadas ${ }^{38}$. Luego, la contundente real cédula del 4 de mayo de 1635 (refrendada el primero de diciembre de 1636) ordenó la realización de las composiciones y canalizar los fondos para la formación de la Armada de Barlovento. Sin procedimientos ni métodos concretos, las diligencias se intentaron efectuar en la provincia de Chalco bajo la conducción del licenciado Juan Guillén Valles. De nuevo, la oposición de los labradores no se hizo esperar, pues denunciaron que los altos salarios del juez de comisión y su comitiva les resultarían más costosos que el valor de sus tierras. Frente a esta situación, el licenciado Guillén negoció con los labradores la suspensión de las diligencias a cambio de un pago de 4,280 pesos por concepto de composición general que comprendía 52 propiedades agrícolas ${ }^{39}$.

Los funcionarios virreinales consideraron que era más perentorio cubrir las urgencias del fisco que conocer la situación agraria del reino, razón por la que resolvieron que la forma más eficiente para cobrar las composiciones era mediante un pago general por todos los vecinos de cada provincia o jurisdicción. Después de la experiencia en Chalco, el procedimiento de composiciones generales se repitió en Huexotzingo y Atlixco durante el gobierno del virrey

36 Sobre los atrasos de las rentas, 27 de mayo de 1605, AGI, México, 26, n. ${ }^{\circ} 53$.

37 Que las comisiones para componer tierras no se den sino conforme a esta ley, Felipe III, San Lorenzo, a 26 de abril de 1618, editado en León Pinelo, 1992, vol. 3: 2054. Real cédula ordenando composiciones y ventas de tierras, debiéndose efectuar en pública subasta y al mejor postor, Felipe IV, Madrid a 27 de mayo de 1631, editado en Solano, 1984: 314-331.

38 Torales, 2005: 54.

39 Jalpa Flores, 1998: 258. 
García de Sarmiento de Sotomayor, Conde de Salvatierra, y luego se implementó como modelo en el resto de las jurisdicciones novohispanas entre 1643 y $1645^{40}$. No entraremos en las vicisitudes de estas composiciones, aunque convendrá hacer un estudio detallado sobre las discusiones que tuvieron los oidores y fiscales de la Real Audiencia, en especial sobre su determinación de ordenar las composiciones de las aguas utilizadas para tierras de riego, tema que marcó un precedente sobre la conversión de los derechos al acceso a recursos de uso común hacia el aprovechamiento exclusivo para beneficio de particulares ${ }^{41}$.

Las composiciones generales fueron fundamentales para la consolidación de las haciendas agrícolas y ganaderas en la Nueva España, porque fueron aprovechadas por los dueños de propiedades rurales para recibir títulos legítimos de las tierras que habían apropiado mediante la simple ocupación. Pero en el ámbito de la recaudación, quedan dudas sobre sus resultados. Con un ánimo por demás optimista, el Conde de Salvatierra le comunicó al rey el 30 de junio de 1644: «aunque conocí el poco fruto que los virreyes mis antecesores han sacado dellas y que los vasallos habían recibido vejaciones de los jueces que se han enviado sin quedar compuestos... lo compuesto hasta aquí y poco que resta llegará a medio millón $»^{42}$. Esta cifra se aproxima a los cálculos realizados en investigaciones recientes sobre la cobranza de composiciones en cerca de 60 jurisdicciones novohispanas ${ }^{43}$. En cuarenta de ellas la recaudación sumó 216.400 pesos, mientras que en el resto se desconocen los montos. Sin embargo, los registros de la Real Caja de México indican que en 1647 ingresaron 56,115 pesos y al año siguiente 56,925 pesos por concepto de composiciones de tierras y aguas, siendo las cantidades más elevadas que se percibieron en este rubro ${ }^{44}$. Conviene advertir que los últimos años en que las composiciones se cobraron como cuenta aparte, es decir, como un rubro desglosado de los ingresos destinados para la Armada de Barlovento, fueron en 1650 y 1651 que corresponden a la cobranza de 10.331 pesos y 2.000 pesos respectivamente. Estas cantidades indican una drástica disminución, pero también señalan inconsistencias entre los informes oficiales, los registros

40 Traslado de las composiciones realizadas en la Villa de Carrión, Valle de Atlixco [1643], solicitado por Cesáreo García, dueño de la hacienda nombrada San Juan Bautista Huеxocuapa, 23 de mayo de 1892, Biblioteca Nacional de México, México (BNM), Tenencia de la Tierra, caja 4, exp. 250, 55 fs. Solano, 1984: 337-352.

41 Carrera, 2018: 148-153.

42 Carta del virrey Conde de Salvatierra: sobre el estado de las composiciones de tierras y aguas en la Nueva España, 30 de junio de 1644, AGI, México, 35, n. ${ }^{\circ}$. 29. f. 1v.

43 Goyas Mejía, 2015: 65.

44 Te Paske y Hernández Palomo, 1976. 
de la Real Hacienda y las liquidaciones contenidas en los títulos de composiciones de las provincias.

En los despachos de composiciones generales de 1643 se les advirtió a los vecinos de las provincias que no excediesen los límites de sus propiedades sin incluir títulos legítimos. ¿Cómo se iba a respetar esta norma si las propias autoridades desconocían la situación de las estructuras agrarias y las dimensiones de las propiedades? Los hacendados pasaron por alto esta condición y continuaron adjudicándose tierras. Aprovechando este escenario y con el argumento de reactivar la Armada de Barlovento, Felipe IV emitió una real cédula el 10 de septiembre de 1662 para implementar de nuevo las composiciones entre sus vasallos en las Indias ${ }^{45}$. Con la redefinición de los rubros fiscales, las recaudaciones por composiciones se incorporaron a la cuenta general para la armada, razón por la que su cobranza dejó de registrarse en los libros de la Real Caja de México. Una vez más, el poder virreinal se retrasó en atender esta particular materia, porque hasta el 24 de septiembre de 1674 el arzobispo virrey fray Payo Enríquez de Rivera ordenó el cumplimiento de los mandamientos de su antecesor, el Marqués de Mancera, decretados en 1668 y 1669 para que todos los poseedores y propietarios de tierras manifestaran sus títulos ${ }^{46}$. Éstos debían presentarse ante la Real Audiencia de forma individual o mediante representante legal para exhibir su documentación, con el fin de que la autoridad virreinal les ratificara los despachos de composiciones generales entregados cuatro décadas atrás. Así lo hicieron los vecinos labradores de la Villa de Carrión en el valle de Atlixco, a quienes se les refrendó la composición de 1643 con la condición de liquidar el adeudo de 117 pesos y cinco tomines ${ }^{47}$. Huelga decir que en las manifestaciones de títulos realizadas entre 1674 y 1678 el gobierno virreinal no hizo más que revalidar el acuerdo con los hacendados y propietarios rurales. Pero no se preocupó por conocer las condiciones de las estructuras agrarias, ni tampoco

45 Vuestra majestad manda que todos los efectos aplicados para la Armada de Barlovento se envien a estos reinos por cuenta aparte para que se vuelva a formar de nuevo como $V$. M. lo tiene resuelto, Madrid, septiembre 10 de 1662, AGN, Reales cédulas originales, vol. 7, exp. 71, fs. 133-134.

46 Para que cualquier receptor desta Real Audiencia que fuere requerido por parte de don Francisco Molinari Anfoso ejecute los mandamientos despachados por el excelentísimo señor virrey Marqués de Mancera según y como en ellos se contiene, México, septiembre 24 de 1674, AGN, Mercedes, vol. 58, sin número de fojas, entre la 8 y 9. Mandamiento del virrey, México, febrero 11 de 1675, AGN, Tierras, vol. 417, exp. 1, f. 66v.

47 Vuestra excelencia declara haber cumplido la Villa de Carrión Valle de Atlixco en haber presentado la composición de tierras y aguas que poseen sus vecinos, 26 de noviembre de 1674, AGN, Mercedes, vol. 58. fs. 12-13. 
por reconocer las tierras realengas ocupadas o cuántos baldíos podían disponerse mediante las subastas públicas. Como un dato adicional, los ingresos de la Real Hacienda en el rubro de la Armada de Barlovento en 1676 fueron de 114,769 pesos, y de 404,845 pesos en 1678 , aunque como se ha señalado, no se conoce lo que correspondió por el cobro de composiciones de tierras y aguas.

LAS REFORMAS A LA POLÍTICA AGRARIA

Al finalizar el siglo XVII la monarquía española atravesaba una profunda crisis económica y política, tanto por los gastos en las guerras contra otros reinos como por las disputas por el trono entre los Habsburgo y los Borbones. La Real Hacienda necesitaba dinero con urgencia y el Real Consejo emprendió reformas administrativas y fiscales para el cobro inmediato de los derechos de sus regalías. Con respecto a la regularización agraria, la Corona buscó efectuar una distribución más ordenada de las tierras a través de la venta de los baldíos y, al mismo tiempo, convertir a los poseedores en legítimos propietarios mediante el pago de derechos a la titulación y las composiciones. En esta formulación subyacía el supuesto de que el derecho exclusivo de acceso a la tierra - es decir, la propiedad perfecta - sería el principio fundamental de la productividad de las colonias americanas. Por dicha razón sostenemos que la reforma a la política agraria no derivó solamente de un contexto de inmediatez económica, sino también por los cambios ideológicos y conceptuales acerca de los derechos a la propiedad. En el proyecto de la Corona por regir sobre la ocupación del suelo se observa que el concepto de propiedad agraria estaba perdiendo las características del dominio señorial, es decir, las formas de acceso a la tierra mediante el dominio útil concedido por los nobles a sus vasallos. De este modo, el amplio abanico de derechos agrarios, como la posesión natural, la posesión civil de buena fe, el dominio directo, el dominio útil y la enfiteusis, entre otros, fueron considerados por la doctrina jurídica como imperfectos y quedaron supeditados al dominio absoluto, el cual comenzó a ser entendido como la forma de propiedad perfecta y privativa, toda vez que se comprobara su legitimidad por medio de títulos ${ }^{48}$.

Para llevar a la práctica las reformas agrarias fue preciso transferir las facultades que gozaba la figura virreinal hacia nuevas instancias encargadas exclusivamente para la vigilancia, control y ejecución de las composiciones y

48 Carrera, 2018. 
las subastas de los baldíos. La tibieza de los virreyes fue uno de los argumentos para que el Real Consejo propusiera la creación de un organismo dedicado a la aplicación de los mecanismos de regularización. Incluso, aconsejó retirar las prerrogativas de las corporaciones y comunidades que las eximían de estos requerimientos hacendarios. Así, en la real cédula del 27 de junio de 1692, Carlos II anunció su consideración sobre las diversas dependencias que tenían a su cargo los virreyes y decidió aligerar sus responsabilidades, por lo que designó al licenciado don Bernardino de Valdés y Girón, miembro del Consejo, Cámara y Junta de Guerra de Indias, para el cobro de las composiciones en las provincias del Perú y Nueva España, con amplias atribuciones para subdelegar a ministros en cada una de las audiencias. Por primera vez aparece el nombre de la Superintendencia del Beneficio y Composición de Tierras en un documento oficial, instancia que fue dirigida por Valdés y Girón. La cédula informó al virrey Conde de Galve «que ha parecido avisaros para que estéis advertido de esta resolución y ordenaros y mandaros (como lo hago) fomentéis y asistáis al dicho don Bernardino de Valdés y sus subdelegados, dándoles el favor y ayuda siempre que os le pidieren y hubieren menester» ${ }^{49}$.

La política de regularización de la propiedad rural alcanzó un punto de maduración con la Superintendencia, pues esta dependencia centralizó las labores de la regularización agraria y tomó cargo de la administración de las cobranzas de este rubro. El 30 de octubre de 1692 el rey promulgó dos cédulas que perfilaron las actividades de sus funcionarios. En una anunció el interés de la Corona por emprender una campaña militar y la necesidad para asistir a los gastos del ejército, motivo por el que recurrió a «urgencias extraordinarias» para el cobro de los bienes realengos «por razón de venta y de que no se haya dado satisfacción en el todo o en parte». Los plazos para cumplir con estos pagos eran de seis meses en los reinos de Castilla y Aragón, mientras que para Italia y las Indias fue de un año. Esta disposición dio un giro a la política agraria porque debía ser acatada «sin excepción de personas, ni comunidades de cualquier estado y calidad que sean, porque a todos reservo su derecho», dando a entender que los indios y los eclesiásticos debían responder a los requerimientos de la Real Hacienda y someter sus posesiones a los procedimientos de escrutinio. En esta ley se enfatizó que en las Indias aún había «muchos poseedores de tierras que pertenecen al real patrimonio

49 Al virrey de la Nueva España, avisándole se ha dado a don Bernardino de Valdés y Girón, del Consejo, Cámara y Junta de Guerra de Indias, la Superintendencia del Beneficio y Composición de Tierras de aquellas provincias y las del Perú, Madrid, junio 27 de 1692, AGN, Reales cédulas, vol. 24, exp. 108, fs. 397-397v. Editada por Solano (1984: 375) pero con fecha de 1 de julio de 1692. 
sin título, ni justas causas por donde les pertenezcan», y que anteriormente había dado la comisión a los virreyes, presidentes y gobernadores de las provincias para la subasta de las tierras realengas y la admisión de composición a los poseedores irregulares. Ahora, el rey delegaba esta comisión a Bernardino de Valdés y Girón para que procediera «a la restitución de dichas tierras, indultando a los que las poseyeren en la cantidad que tuviéredes por proporcionada, despachándoles títulos de ellas con calidad que dentro del término que está dispuesto para las encomiendas haya de llevar confirmación mía de las que así beneficiáredes o indultáredes», con la advertencia de que las tierras de los remisos «pasareis a venderlas». El cobro de estos derechos estaría a cargo de un funcionario nombrado por Valdés y Girón para enviar los caudales en las flotas a España en una cuenta aparte «y con separación y puntual declaración de las partidas que se compusiere ${ }^{50}$. La otra real cédula sólo fue un breve anuncio a los virreyes y presidentes de las audiencias para auxiliar a los subdelegados nombrados para cada una de las audiencias ${ }^{51}$.

A la muerte de don Bernardino de Valdés y Girón, la Superintendencia del Beneficio y Composiciones de Tierras quedó a cargo de don Francisco Camargo y Paz a partir del 6 de junio de 1696, «atendiendo a éstas y las demás circunstancias que pide la materia» y «a vuestros subdelegados, en la misma jurisdicción, poderío y comisión que tuvo y concedí a don Bernardo de Valdés y personas en quien subdelegó» ${ }^{52}$. A los cuatro años de su elección como superintendente, don Francisco de Camargo y Paz falleció y fue sustituido por el ministro Juan de Castro Gallegos, quien recibió su nombramiento el primero de octubre de $1701^{53}$.

La Superintendencia no sólo tenía bajo su responsabilidad la recaudación de las composiciones atrasadas o las ventas de realengos. En el marco de la

50 Creación de la Superintendencia del Beneficio y Composición de Tierras (en el Consejo de Indias, con subdelegados en América): para robustecer el carácter fiscal del ramo de tierras y vigilar directamente desde España las enajenaciones de los bienes realengos, San Lorenzo de El Escorial, 30 de octubre de 1692, editado en Solano, 1984: 377-380.

51 Al virrey de la Nueva España avisándole que se ha dado comisión a don Bernardino de Valdés y Jirón del Consejo, Cámara y Junta de Guerra de indias para poner cobro en lo que se está debiendo a la real hacienda por razón de compra de villas y para la composición de tierras, San Lorenzo de El Escorial, 30 de octubre de 1692, AGN, Reales cédulas originales, vol. 24, exp. 133, fs. 522-523v.

52 Nombramiento del segundo superintendente del Beneficio y Composición de tierras: con idénticas funciones, comisiones y prerrogativas que en 1692, Buen Retiro, 6 de junio de 1696, editado en Solano, 1984: 386.

53 Instrucción del juez subdelegado de composición de tierras y baldios, juan de Castro Gallegos, 28 de noviembre de 1701, Madrid, AGI, Indiferente, 1520. 
fundación de esta instancia gubernamental fue cuando la Corona mostró mayor interés por uniformar las diversas formas de posesión de la tierra que eran consideradas como imperfectas, es decir, por afianzar el derecho a la propiedad absoluta. Al mismo tiempo, el gobierno español exigió la composición de la propiedad comunal y corporativa cuando retiró las prerrogativas a los pueblos de indios y las corporaciones eclesiásticas, pero no para promover su enajenación, sino para distinguir sus tierras de las propiedades privadas y de los baldíos. Aquí vale la pena subrayar que, a pesar de sus esfuerzos, la monarquía no logró homogeneizar - ni mucho menos anular - todos los derechos de posesión de la tierra, debido a las características de las estructuras agrarias en cada provincia, las relaciones e intereses de los grupos sociales con las autoridades locales y el arraigo de las prácticas basadas en la costumbre. El caso de la península de Yucatán ilustra muy bien lo anterior, en el sentido de que las composiciones realizadas en 1710 no modificaron inmediatamente la estructura agraria de la provincia, porque la enfiteusis y la aparcería continuaron siendo los principales mecanismos de acceso a las tierras y eran practicados tanto por los propietarios de estancias y haciendas como por los pueblos mayas todavía a principios del siglo XIX ${ }^{54}$.

\section{El Juzgado Privativo de Tierras y Aguas de la Nueva España}

Para que la nueva política agraria pudiera pasar de la planeación a la práctica, el Real Consejo instruyó al superintendente que delegara a ministros y oidores de las Reales Audiencias para instaurar los Juzgados Privativos de Tierras. Desde España, Bernardino de Valdés y Girón nombró el 27 de enero de 1693 a los oidores de la Real Audiencia de México, Francisco Marmolejo, Juan de Arechaga y a Pedro de Labastida, para el cobro de composiciones de tierras y venta de baldíos en la Nueva España, «por la experiencia que tienen de su puntualidad y buenos procedimientos en el real servicio». El nombramiento señaló que «en caso de muertes, ausencias y enfermedades u otro cualquier impedimento que cada uno suceda, aunque hayan dado principio a ella, para que puedan continuar en las diligencias tomando los autos el siguiente que va nombrado y por su falta el tercero en orden» ${ }^{55}$. El licenciado Francisco Feijoo Centellas se ocupó del Juzgado Privativo de Tierras en la

\footnotetext{
54 Carrera, 2017.

55 Cumplimiento a la real cedula sobre composición de tierras para poner en cobro lo que se estuviera debiendo por compras de villas, lugares, jurisdicciones, dehesas, tierras, bosques, plantios, alcabalas, cientos, pechos o derechos y otros cualesquiera cosas que se
} 
jurisdicción de la Audiencia de Nueva Galicia ${ }^{56}$. Dos años después, el licenciado don Pedro de Labastida asumió la dirección del Juzgado Privativo de Tierras y Aguas de México, pues este cargo debía ser ocupado por el oidor más antiguo de la audiencia. Durante su gestión fueron designados jueces de comisión a las provincias para iniciar con las diligencias de revisión de títulos y mensura de terrenos. Por primera vez se realizaron vistas de ojos y mediciones a las propiedades de españoles, mestizos y otras castas, al tiempo que se comenzaron a deslindar y tasar los bienes de comunidades de algunos pueblos y también las tierras patrimoniales de caciques e indios principales. A pesar de que estos jueces de comisión no lograron concluir las diligencias en sus jurisdicciones asignadas, sus trabajos abrieron brecha para las composiciones que se realizaron durante las dos primeras décadas del siglo XVIII.

Al parecer, durante la gestión de los superintendentes Francisco Camargo y Paz y Juan de Castro Gallegos no hubo grandes avances en la cobranza de composiciones, porque fue hasta que el licenciado Luis Francisco Ramírez de Arellano asumió la Superintendencia el 15 de agosto de 1707 cuando delegó el Juzgado Privativo de Tierras y Aguas de México al oidor don Francisco de Valenzuela Venegas, quien a la postre decretó los edictos que instruyeron a nuevos jueces de comisión para efectuar las diligencias. El primero de estos edictos fue promulgado el 6 de agosto de 1711, que mandó a los jueces de comisión:

... con término de treinta días, haciendo saber a todas y cualesquier personas de cualquier preeminencia, dignidad, estado o calidad que sean, ciudades, villas, pueblos, lugares, conventos, comunidades, hospitales, cofradías y hermandades que tuvieren en el distrito y jurisdicción de los dichos partidos, haciendas, estancias, ranchos, ingenios, casas de campo, sitios, tierras, solares, huertas, heredades y otras fincas y bienes de los expresados en mi comisión ${ }^{57}$.

En este plazo los jueces de comisión tenían que revisar los títulos de los propietarios y llevar a cabo las mediciones de sus terrenos para reconocer quiénes estaban exentos del pago por derechos de composición y «a los que tuvieren faltas, vicios, defectos, nulidades, excesos, demasías, introducción, restituciones o que sea de su cargo dar alguna satisfacción...les admita a indulto y composición en la cantidad que fuere proporcionada». Las vistas de

hayan vendido, mayo 11 de 1695, AGN, Reales cédulas duplicadas, vol. D40, exp. 126 bis, fs, 214-216.

56 Solano, 1984: 387.

57 Despacho del 6 de agosto de 1711 emitido por el juez privativo para las composiciones según la real cédula del 15 de agosto de 1707, inserto en el expediente: Provincia de Meztitlán de la Sierra, años de 1711, 1712, 1713, AGN, Tierras, vol. 3038, exp. 1, fs. 2-9. 
ojos debían efectuarse con la asistencia de testigos, vecinos y autoridades de los pueblos de indios comarcanos y, sobre todo, de «sujetos y personas que los tuvieren con testigos de toda ciencia y conciencia y experimentados» que fungirían como agrimensores y estimarían las tasaciones de las superficies. En caso de que alguna propiedad presentara una ocupación indebida, los jueces de comisión debían sacar a pregón los espacios reconocidos como demasías por término de treinta días, tiempo en el que debían admitir «las posturas, pujas y mejoras que se hicieren y asignando día y haciéndoselo saber a las partes los rematará en pública almoneda en los mejores y mayores postores que hubiere». A pesar del tono amenazante, el edicto brindó a los propietarios y ocupantes de demasías la posibilidad de denunciar por sí mismos las tierras que se ocuparan sin títulos para que las compusieran y reservarlas de la subasta pública. También, el edicto arbitró como nulas las «composiciones que hubieren hecho los excelentísimos señores virreyes y presidentes sin facultad expresa de componer desde el día que se les prohibió, que fue desde veintiséis de abril del año de seiscientos y dieciocho» ${ }^{58}$. En otras palabras, se ordenó que se verificaran si los títulos de composiciones generales del siglo XVII que conservaban los vecinos de las provincias contaban con facultad real.

Con respecto a las composiciones de los naturales, en el edicto se señaló:

... con advertencia de que éstos estando congregados y con pueblo en forma se les están concedidas por cada viento seiscientas varas y que en la [venta] y composición de las tierras que poseyeren y necesitaren para sus labores, siembras y crianza sea y debe pro[ceder] con suavidad, templanza y moderación sin [exceso] de rigor con ellos ni causarles perjuicios, [costas], daños ni vejaciones ni despojarles de la posesión en que estuvieren sin título o con él, sino que constando de ella por información con cantidad de tierras sus términos y linderos les admita los ofrecimientos que hicieren y me remita los autos sin exceder ni pasar a otra diligencia y que también se ha de portar con templanza ${ }^{59}$.

El juez privativo no estaba haciendo referencia a las ordenanzas que desde el siglo XVI se dictaron para intentar resolver los constantes conflictos entre pueblos y propietarios españoles, las cuales habían establecido una distancia de mil varas (838 metros) para las estancias ganaderas y quinientas varas (419 metros) para las tierras de labor «desviado de la población y casas

58 La real cédula del 26 de abril 1618 dicta: «los nuestros virreyes no an de dar comisiones para la rrestitución ni para la compusición si no fuere con evidente necesidad y avisándonos primero de las causas que los mueben para haçer las dichas composiciones». León Pinelo, 1992, vol. 3: 2054.

59 Despacho del 6 de agosto de 1711 emitido por el juez privativo para las composiciones según la real cédula del 15 de agosto de 1707, AGN, Tierras, vol. 3038, exp. 1, fs. 7v-8. 
de los indios». Más bien se refería a la interpretación que se hizo de estas leyes y que culminó en el reconocimiento de medidas de superficie para bienes de comunidades, expresadas a través de la frase «tierras por razón de pueblo» ${ }^{60}$. Dicho reconocimiento comenzó a reforzarse con la real cédula del 4 de junio de 1687 que concedió derechos a los pueblos por seiscientas varas «y las más que hubiese menester», que debían ser contadas desde «la última casa del lugar, así a la parte de Oriente y Poniente, como de Norte a Sur» ${ }^{61}$. Luego, el espacio de las seiscientas varas se constituyó como núcleo básico de los bienes de comunidad cuando la real cédula del 12 de julio de 1695 determinó que su medición se tenía que realizar por cada viento y desde las iglesias o los centros de los poblados y no desde las últimas casas o jacales ${ }^{62}$. Esta resolución resultó ser muy conveniente —en términos prácticos- para los oficiales del Juzgado Privativo de Tierras, porque era preciso deslindar las tierras de los pueblos para distinguirlos de los baldíos que podían rematarse en subasta pública. A los pueblos se les medirían todas sus tierras, reservando del pago de composición las seiscientas varas y las que poseyeran con respaldo de títulos legítimos (mercedes), pero aquellas que quedaran fuera de este espacio y que no estuvieran respaldadas por documentación oficial quedaban sujetas al pago de composición.

Parecía que el edicto de Valenzuela Venegas no despojaba a los pueblos, aunque sí cuestionó sus derechos a las superficies que habían conservado desde tiempo inmemorial y a las demarcaciones de sus congregaciones. En otro trabajo nos ocupamos de analizar los resultados de las composiciones en los pueblos de indios, cuya problemática radicó en la yuxtaposición de derechos jurisdiccionales y de la propiedad comunal ${ }^{63}$. Pero aquí es importante subrayar que el edicto marcó el precedente para que los pueblos obtuvieran la titularidad de sus tierras, muchos de ellos por primera vez.

El juez privativo logró retirarles los privilegios a los religiosos y corporaciones de la Iglesia, algo que no habían conseguido los virreyes, pues como se asentó en el edicto:

... también se ha de portar con templanza en las tierras que fueren de eclesiásticos, comunidades, conventos, monasterios y ministros exceptos, pero con condición de

\footnotetext{
60 García Martínez, 2002.

61 Galván Rivera, 1998: 192-195.

62 Real cédula a la Audiencia de México admitiendo las reclamaciones de los labradores y corrigiendo las medidas entre pueblos de indios y estancias, debiendo medirse las 600 y 1100 varas establecidas entre ambos desde el centro de los pueblos de indios, Madrid, 12 de julio de 1695, editado en Solano, 1984: 384-385.

63 Carrera, 2015a.
} 
que en materia de adquisición de tierras y justa posesión de ellas en estas partes de las Indias no hay ni puede haber excepción, fuero ni privilegio alguno y que cualquiera que pretenda tener derecho a ellas debe exhibir título de su majestad ${ }^{64}$.

Por último, don Francisco de Valenzuela Venegas fijó el salario de los jueces de comisión en cinco pesos por cada día de las diligencias «y a los demás ministros lo que les tocaren por aranceles», gasto que debía salir de los bolsillos de los propietarios y las repúblicas de naturales de los pueblos cuyos terrenos fuesen mensurados, deslindados y titulados. Las autoridades locales (alcaldes mayores, corregidores y tenientes de justicia) tenían la obligación de asistir a los jueces de comisión so «pena de quinientos pesos aplicados a los costos y gastos de esta comisión y del interés de su majestad». Y en caso de que «alguna persona se sintiera agraviada» por los jueces de composiciones, sería el Real Consejo de Indias quien resolvería las controversias, pues ante todo estaban los intereses del rey y la Real Hacienda ${ }^{65}$.

Los jueces de comisión comenzaron con las diligencias en las jurisdicciones que les fueron asignadas, primero con las notificaciones a los vecinos y autoridades de los pueblos, siguieron con la toma de declaraciones de los testigos, después con las revisiones de los títulos y luego con las vistas de ojos y deslindes de los predios. Estas diligencias produjeron autos por cada una de las propiedades, los cuales contenían los nombres de los dueños, la documentación probatoria, las superficies reconocidas por títulos y las que se apreciaran como demasías, el avalúo de los tanteadores y el parecer de los jueces de comisión con las cantidades reguladas por el pago de composición. La misma información se registró en los autos de los bienes de comunidad de los pueblos, aunque en estos casos la instancia que gozaba de la titularidad era el común de naturales.

El 10 de enero de 1712 don Francisco de Valenzuela Venegas decretó una provisión a los alcaldes mayores porque algunos jueces de comisión «han remitido lo que han actuado, que enterados los servicios y composiciones a las partes les ha dado su despacho a su satisfacción con expresión de la cantidad que han exhibido, y otros faltando a esta norma han entregado a las partes sus autos de suerte que no han ocurrido con ellos porque con este hecho lo han dejado a su voluntad no debiendo ser así». Por eso, ordenó a las justicias locales:

64 Despacho del 6 de agosto de 1711 emitido por el juez privativo para las composiciones según la real cédula del 15 de agosto de 1707, AGN, Tierras, vol. 3038, exp. 1, f. 8.

65 Ibidem, fs. 8v-9. 
... hagan comparecer a todos los pueblos de indios, dueños y poseedores de tierras, y aguas que hubiere en su jurisdicción de cualquier estado, calidad, o condición que sean, y a los que fueren eclesiásticos le ruego y encargo para que manifiesten y demuestren los despachos que tuvieren por donde conste haber enterado las cantidades en que se han compuesto, o en que han comprado y beneficiado tierras y aguas a mis comisarios ${ }^{66}$.

Los autos rubricados por este juez privativo podían ser devueltos a los propietarios, pero «los que no estuvieren de esta forma los recojan, y me los remitan poniendo también razón de los que fueren ejecutando». Los remisos contaban con un plazo para presentarse ante el juzgado y liquidar su regularización. Para tener mayor conocimiento de quiénes ya habían cumplido, ordenó informes pormenorizados «en que expresen y digan si demás de las tierras y aguas que se manifestaron ante mis comisarios, y de que conocieron, e hicieron autos, hay otras en su distrito y jurisdicción, así que se han poseído y estén actualmente poseyendo como baldías y realengas, que se deban beneficiar por cuenta del Real Patrimonio haciendo una breve memoria y relación jurada». Los autos cerrados y los informes debían enviarse al Juzgado en un plazo de 50 días, so pena de 2.000 pesos $^{67}$.

Jueces de comisión y justicias locales actuaron conforme a la última provisión de Valenzuela Venegas y llegaron a concluir las diligencias en la mayoría de las jurisdicciones novohispanas. Todo apuntaba a que el camino trazado para la regularización era el correcto y que la meta estaba a punto de alcanzarse. Sin embargo, el nombramiento del licenciado Joseph de Agustín de los Ríos y Berriz a la dirigencia de la Superintendencia del Beneficio de Composiciones el 26 de octubre 1715 obstaculizó el último trayecto del procedimiento de composiciones, al menos en la Nueva España. En el Juzgado Privativo de Tierras se promovió al oidor Félix Suárez de Figueroa, quien asumió el cargo el 16 de febrero de 1716 y expidió un decreto el 12 de agosto con el que ordenó a los alcaldes mayores exhortar a la población de sus jurisdicciones a presentarse en un periodo de 60 días frente a las nuevas autoridades del juzgado con «las mercedes, títulos y recaudos que tocaren a la propiedad y posesión de lo que tuvieren y poseyeren, haciéndolo asimismo de los despachos que se les hubieren dado de indultos o composiciones por

66 Provisión a los alcaldes mayores y sus lugartenientes para la revisión de los autos efectuados por los jueces de comisión para las composiciones de tierras y aguas, 10 de enero de 1712, impreso inserto en el expediente correspondiente a la Jurisdicción de Cholula, Puebla, 10 de enero al 29 de julio de 1712, BNM, Fondo Reservado, Tenencia de la Tierra, caja 5, exp. 263, f. $1 \mathrm{v}$.

67 Ibidem, fs. 1v-2. 
los señores jueces que han sido de dicha comisión». Su argumento era esclarecer las situaciones donde hubieran «faltas, vicios, defectos y nulidades con que se hallaren excesos, huecos y demasías», pues en caso de encontrar una situación irregular, los interesados debían «dar íntegra satisfacción y pago a su Majestad». Esta disposición, en teoría, exentó a quienes ya contaran con título de composición e indulto entregado por mano de su antecesor, pero consideraba que era preciso volver a revisar la documentación para tener certeza de la veracidad de los despachos. Y es que Suárez de Figueroa sostenía que los jueces de comisión habían incurrido en diversas faltas en detrimento de terceros, por lo que «han dimanado muchos pleitos, por haber incluido las tierras de que no tenían posesión, que ha obligado a los que las gozaban a pedir restitución y otros recursos legales». Lo cierto era que las facultades del juez privativo de tierras no comprendían resolver litigios entre propietarios, toda vez que estas atribuciones correspondían exclusivamente a los virreyes y presidentes de las audiencias. En este sentido, el título de Juzgado Privativo de Tierras y Aguas era nominal porque sus jueces estaban impedidos de emitir sentencias en juicios de materia agraria. Por último, mandó a los alcaldes mayores cesar a los jueces de comisión que habían sido nombrados por Valenzuela Venegas «y dentro de ocho días primeros siguientes al de la notificación, los presenten ante mí y en este juzgado con todos los autos que hubieren ejecutado, y cuenta y relación jurada en forma de uno y otro». Dicho informe debía ir acompañado de un mapa de «todas las haciendas, ranchos, aguas y demás que se comprende en esta comisión y va expresado, y sus dueños y poseedores, pueblos, ciudades, villas y lugares que hubiere en su distrito, sin omitir cosa alguna a fin de tenerlo presente en este juzgado» ${ }^{68}$.

El 10 de marzo de 1717 se decretó una real cédula que colocó al licenciado Diego de Zúñiga al frente de la Superintendencia del Beneficio de Composiciones. Este reordenamiento en el Real Consejo de Indias provocó que don Félix Suárez de Figueroa fuera removido de su cargo y se devolviera la dirección del Juzgado Privativo de Tierras y Aguas de México a don Francisco de Valenzuela Venegas el 13 de mayo de ese mismo año. El reinstaurado juez privativo publicó un decreto el 25 de octubre para que los alcaldes mayores y sus tenientes de justicia:

68 Despacho de don Félix Suárez de Figueroa, juez privativo de composiciones de tierras de Nueva España, 12 de agosto de 1716, impreso inserto en el expediente: Autos y diligencias hechas por la justicia de Chicontepec en virtud de despacho del señor juez privativo de indultos, ventas y composición de tierras de este reino, 1716, Archivo Histórico Judicial del Estado de Puebla, Puebla (AHJP), exp. 2802, 3 fs. Editado en Solano, 1984: 407-411. 
... hagan cesar a todos los comisarios que hubiere en su jurisdicción, y que exhiban las comisiones, y despachos que han tenido y tuvieren, y todos los autos que han hecho, y declaren todo lo que han ejecutado durante el tiempo que las han ejercido, las cantidades que han percibido y recaudado ${ }^{69}$.

Exigió que los autos fueran enviados a su juzgado en cuadernos individuales con la expresión de las cantidades ofrecidas por los dueños y las tasaciones de los agrimensores para el inmediato pago de los adeudos. Al igual que su antecesor, les ordenó a las autoridades locales una detallada relación «verídica, fiel y legal de todos los que faltaren por componerse», además de aquellos que ya habían pagado pero que todavía no recibían nuevos títulos de sus tierras. Dicha memoria debía contener «los baldíos por beneficiar y vender, todo muy pormenor y con toda expresión y claridad para que venga en conocimiento de ello»y así evitar mandar a otros jueces de comisión para el cumplimiento de su mandamiento. Fijó un plazo de 60 días para que los alcaldes mayores enviaran los autos e informes originales cerrados y sellados, con la advertencia de una multa de 500 pesos «y de que irá persona a su costa a ejecutarlo» ${ }^{70}$.

En 1718 don Francisco de Valenzuela Venegas expidió tres mandamientos, con fechas de 6 de mayo, 18 de junio y 2 de septiembre, de los cuales sólo hemos podido hallar el primero. En este mandamiento el juez privativo giró órdenes a los alcaldes mayores para finalizar de una vez por todas las diligencias que estuvieran realizando jueces de comisión y enviar de manera expedita los autos concluidos y sus informes. Esto lo debían hacer con la mayor claridad, porque «hay varios cuadernos de autos en la escribanía de este juzgado privativo, y habrá otros en poder de los comisarios que no se sabe los que son por no haber dado cuenta en forma los más de ellos como mandé en los despachos citados, y [otros más] en el de las partes e interesados». En los títulos de composición que debían recibir los propietarios regularizados se tendría que asentar una declaración en la que constara que no eran acreedores a otros pagos, ya fuese por haber conservado sus mercedes, porque demostraron sus composiciones generales del siglo XVII sin excederse de sus límites o porque cumplieron con la liquidación por las demasías que les fueron

69 Despacho del juez privativo a los alcaldes mayores para la conclusión de composiciones, 25 de octubre de 1717, copia inserta en el documento Autos y diligencias hechas por la real justicia de la ciudad de Cholula en virtud del despacho del señor lic. don Francisco de Valenzuela Venegas, caballero del Orden de Santiago, del Consejo de su majestad, su oidor más antiguo de la Real Audiencia y juez privativo para las composiciones e indultos de tierras y aguas, BNM, Fondo Reservado, Tenencia de la Tierra, caja 7, exp. 341, f. 1v.

70 Ibidem, fs. 1-2v. 
tasadas. Asimismo, en este mandamiento el juez privativo definió los mecanismos para denunciar tierras realengas y obtenerlas por medio de la subasta pública, pues los vecinos interesados estaban adjudicándose los baldíos a través de las composiciones, lo cual contravenían las reales cédulas sobre la materia. A partir de entonces, los solicitantes debían señalar los baldíos que deseaban enajenar para hacerlo del conocimiento de los demás vecinos por pregón durante treinta días, «admitiendo en ellos las posturas, pujas y mejoras que se hicieren, teniendo especial atención con los denunciadores, rematando en los mejores y mayores postores que hubiere, sin bajar de los aprecios y asegurados los enteros». Los escribanos públicos y los tenientes de justicia contaban con un plazo de 60 días para mandar al juzgado una relación o memoria con los nombres de todos los dueños y sus propiedades, distinguiéndolos de los que ya habían recibido nuevos títulos de composición de aquellos que aún faltaban por obtenerlos. Con base en esta información el juez privativo redactaría su reporte para dar cuenta de lo ejecutado a las autoridades de la Superintendencia ${ }^{71}$.

El juez privativo actuaba con autonomía y sólo requería de la asistencia del virrey en caso de que sus oficiales «fueren omisos e inobedientes», apremiándolos con el retiro de sus cargos y sustituyéndolos con «otros en su lugar que cumplan y ejecuten las reales órdenes». Pero una orden enviada desde el Consejo de Indias el 30 de octubre de 1718 le otorgó la facultad al virrey Marqués de Valero para que «nombre un ministro de los de esa Audiencia que tuviere por más conveniente y de su satisfacción» para que cumpliese con el cargo de juez privativo de tierras. Al igual que sus antecesores, éste debía subdelegar la comisión en personas que tuviere por propósito, vigilar las actividades de estos jueces de comisión e informar sobre lo que estuviese cobrando "para que su majestad se halle en inteligencia». Al virrey se le encomendó que estuviera pendiente de lo que el juez privativo de tierras obrara «y procure con su celo tenga el buen efecto que por su medio se espera ${ }^{72}$. Más tarde, el 19 de agosto de 1720 el Consejo de Indias resolvió devolver las facultades al licenciado Diego de Zúñiga para designar a los jueces privativos de tierras en las audiencias. En una carta fechada el 7 de octubre de ese mis-

71 Despacho de don Francisco de Valenzuela Venegas, juez privativo de composiciones de tierras de Nueva España, 6 de mayo de 1718, copia inserta en el expediente Autos hechos sobre las tierras de la jurisdicción de Chicontepeque donde constan los que se hallan compuestos, relación jurada e informe sobre todas las diligencias ejecutadas. Chicontepeque. $1718,1719,1720$, AHJP, exp. 2875, f. 4v.

72 Este documento está registrado con un título incorrecto: Recomendaciones de la que hace a don Félix Suárez de Figueroa, Madrid, octubre 30 de 1718, AGN, Reales cédulas originales, vol. 39, exp. 148, fs. 320-321v. 
mo año se informó al virrey novohispano sobre esta determinación, «para que luego que el mencionado don Diego de Zúñiga nombre subdelegados de la referida comisión en esas provincias, se les dé el uso según se ejecutaba por lo pasado», suspendiendo y relevando a las personas que hubiesen sido asignadas para las cobranzas pendientes ${ }^{73}$.

Durante la segunda década del siglo XVIII, en la escribanía del Juzgado Privativo de Tierras se recibieron y acumularon los expedientes de las diligencias, los informes de jueces de comisión y alcaldes mayores, las copias de los autos y despachos entregados a los propietarios, los mapas insertados en las relaciones juradas y quizá hasta documentos de demarcación de congregaciones de pueblos. Este era un hecho que confirmaba que los mandamientos y edictos girados por los ministros del Juzgado Privativo de Tierras fueron cumplidos en la mayoría de las jurisdicciones novohispanas, que a la postre conformaron un acervo documental de carácter agrario.

Los ordenamientos legales y las acciones de este organismo burocrático no se deben sobrevalorar, ni mucho menos considerar como un éxito absoluto, pues en ciertas provincias los jueces de comisión se toparon con la reticencia de los vecinos, que los orillaban a negociar para suspender las mediciones de sus tierras, ofreciéndoles el pago íntegro de su suelo a cambio de nuevos títulos de propiedad, como sucedió en la provincia de Yucatán en $1710^{74}$. No obstante, todo lo anterior indica que en estos años el aparato burocrático encargado de la regularización agraria ya caminaba por su propio pie y que su estructura se mantendría sin mayores modificaciones hasta 1735, cuando se nombró al licenciado don Antonio de Pineda para la Superintendencia del Beneficio de Composiciones y se promulgaron disposiciones para la ejecución de nuevas composiciones de tierras $^{75}$.

\section{REFLEXIONES FINALES}

El análisis de la regularización agraria durante el periodo colonial no debe limitarse al enfoque económico ni tampoco al aspecto exclusivo de los derechos de propiedad. La fundación de los Juzgados Privativos de Tierras se dio en un contexto donde intervino la crisis política y económica de la monarquía española, sus conflictos bélicos con las distintas coronas europeas, la insisten-

73 Composición de tierras. Nombrase juez de ellas a un ministro del Consejo, octubre 7 de 1720, AGN, Reales cédulas originales, vol. 41, exp. 54, f. 199v.

74 Carrera, 2015b.

75 Solano, 1984: 414. 
cia de la Real Hacienda por aumentar sus fondos con los cobros de derechos por los arbitrios, el desconocimiento de las estructuras agrarias en la mayor parte de las provincias de las Indias y, sobre todo, los cambios conceptuales acerca de los derechos de dominio territorial y la propiedad. Así, el desarrollo de la política de regularización de la propiedad rural fue un tema complejo que ocupó a los ministros de la Corona en ambos lados del Atlántico, específicamente en el funcionamiento de instancias y actores que tuvieron impacto en los ámbitos locales.

Las disposiciones que emanaron de la Superintendencia del Beneficio y Composición de Tierras cimentaron el andamiaje para la construcción de nuevos cuerpos burocráticos. Los Juzgados Privativos de Tierras en las reales audiencias de las Indias representaron la materialización de la política agraria y fiscal de la Corona, mientras que a los jueces privativos de tierras se les debe la promulgación de los mandamientos que definieron los mecanismos para ponerlos en operación. En este artículo se abordaron los edictos y decretos de los jueces privativos de tierras de la audiencia de México, cuya particularidad fue la atención prestada al cumplimiento de las composiciones de tierras en los bienes de comunidad de los pueblos de indios. Este punto merece destacarse porque antes de la creación de la Superintendencia en 1692 los indígenas habían estado exentos de dichos requerimientos en razón de su derecho al dominio útil de sus tierras. Es cierto que las composiciones dieron como resultado la entrega de títulos a los pueblos de indios, lo cual les favoreció para la defensa de sus territorios en futuros litigios contra hacendados, caciques e incluso otros pueblos circunvecinos. No obstante, muchas veces las demarcaciones se realizaron tomando como base los linderos de los pueblos en cuanto entidades territoriales, es decir, en calidad de gobiernos locales con derecho de ejercer el dominio eminente hacia su interior. Sin riesgo de perder el dominio útil, lo anterior provocó que en los pueblos que recibieron la titularidad de sus bienes de comunidad se imbricaran los derechos de propiedad comunal con los dominios jurisdiccionales conferidos por el derecho indiano desde los procesos de congregaciones.

El interés que en los últimos años ha despertado el tema de las composiciones y ventas de baldíos radica tanto en la riqueza de las diligencias que se archivaron en las escribanías de los Juzgados Privativos de Tierras, como los efectos que causó la regularización y el devenir de las estructuras agrarias. Más allá de que nuestro estudio contribuya al conocimiento de un episodio concreto de la historia rural de México, específicamente en el funcionamiento de las instancias agrarias durante el periodo colonial, también tiene como finalidad llamar la atención de otros especialistas para articular las investigaciones en los diversos espacios de la América colonial y avanzar en el cono- 
cimiento de los resultados de la regularización a la propiedad rural y los territorios de los pueblos. Tenemos certeza que sólo una visión global nos permitirá dimensionar su alcance y las respuestas de los distintos grupos sociales de cara a su instrumentación.

\section{BiBLIOGRAFÍA}

Assadourian, Carlos Sempat, "La despoblación indígena en Perú y Nueva España durante el siglo XVI y la formación de la economía colonial”, Historia mexicana, XXXVIII/4 (México, 1989): 419-453.

Assadourian, Carlos Sempat, "Estructuras económicas coloniales: el sistema de las haciendas", Andrea Martínez Baracs y Carlos Sempat Assadourian, Tlaxcala, una historia compartida, siglos XVII-XVIII, México, Consejo Nacional para la Cultura y las Artes, Gobierno del Estado de Tlaxcala, 1991, vol. 10.

Balboa Navarro, Imilcy y Cabrera Prieto, Gerardo, "Descubrir y usurpar. La otra cara de la expedición de Mopox", Millars: Espai i historia, 31 (Castellón, 2008): 49-63.

Borchart de Moreno, Christiana, "Composiciones de tierras en la Audiencia de Quito: el Valle de Tumbaco a finales del siglo XVII", Jahrbuch für Geschichte Lateinamerikas, 17 (Böhlau, 1980): 121-155.

Carrera Quezada, Sergio Eduardo, "Las composiciones de tierras en los pueblos de indios en dos jurisdicciones coloniales de la Huasteca, 1692-1720", Estudios de Historia Novohispana, 52 (México, enero-junio 2015a): 29-50.

Carrera Quezada, Sergio Eduardo, "La política agraria en el Yucatán colonial: las composiciones de tierras en 1679 y 1710", Historia Mexicana, LXV-1/257 (México, julio-septiembre 2015b): 65-109.

Carrera Quezada, Sergio Eduardo, "Entre la regularización y la enajenación: composiciones, denuncias y ventas de tierras baldías en Yucatán, 1679-1827", Relaciones. Estudios de historia y sociedad, XXXVIII/151 (Zamora, verano 2017): 59-92.

Carrera Quezada, Sergio Eduardo, Sementeras de papel. La regularización de la propiedad rural en la Huasteca serrana, 1550-1720, México, El Colegio de México/CIESAS, 2018.

Chevalier, François, La formación de los latifundios en México. Haciendas y sociedad en los siglos XVI, XVII y XVIII, México, Fondo de Cultura Económica, 1999 [1956], segunda reimpresión.

Embriz, Arnulfo y Ruiz, Laura, Guia del Archivo General Agrario, México, Registro Agrario Nacional, Centro de Investigaciones y Estudios Superiores en Antropología Social, 1998, vol. 1. 
Encinas, Diego de, Cedulario indiano. Libro primero de provisiones, cédulas, capítulos de ordenanza, instrucciones y cartas libradas y despachadas en diferentes tiempos por SS. MM., Madrid, Imprenta real, 1596, 4 vols. Facsímil, Alfonso García Gallo (ed.), Madrid, Ediciones Cultura Hispánica, 1945-1946.

Florescano, Enrique, "Formación y estructura económica de la hacienda en Nueva España", Leslie Bethell (ed.), Historia de América Latina. América Latina colonial: vol. 3 Economía, Barcelona/Cambridge, Editorial Crítica/Cambrigde University Press, 1990: 92-121.

Galván Rivera, Mariano, Ordenanzas de tierras y aguas. Facsímil de la quinta edición de 1868, Teresa Rojas (ed.), México, Centro de Investigaciones y Estudios Superiores en Antropología Social/Archivo Histórico del Agua/Registro Agrario Nacional, 1998.

García Martínez, Bernardo, "La ordenanza del Marqués de Falces del 26 de mayo de 1567: una pequeña gran confusión documental e historiográfica", Jahrbuch für Geschichte Lateinamerikas, 39 (Böhlau, 2002): 161-191.

Glave, Luis Miguel, "Gestiones trasatlánticas. Los indios ante la trama del poder virreinal y las composiciones de tierras (1646)", Revista complutense de Historia de América, 34 (Madrid, 2008): 85-106.

Goyas Mejía, Ramón, "Las composiciones de tierras de 1643 en la Nueva España", Revista de Historia Iberoamericana, 8/2 (Madrid, 2015): 54-75.

Jalpa Flores, Tomás, La tenencia de la tierra en la provincia de Chalco, siglos XV al XVII, México, UNAM, Facultad de Filosofía y Letras, 1998. Tesis de maestría en Historia,

Jalpa Flores, Tomás, Tierra y sociedad: la apropiación del suelo en la región de Chalco durante los siglos XV-XVII, México, Instituto Nacional de Antropología e Historia, 2008.

Jiménez Gómez, Juan Ricardo, Composición de tierras de los vecinos de Querétaro con su majestad en 1643, Querétaro, Universidad Autónoma de Querétaro, 2003.

Jurado, M. Carolina, ““(...) muy mañoso para esto’. Comisiones para don Pedro Osores de Ulloa, segundo juez de composiciones de tierras de Charcas, 15941596", Corpus. Archivos virtuales de la alteridad americana, 4/2 (julio-diciembre 2014), http://corpusarchivos.revues.org/1202; DOI: 10.4000/corpusarchivos.1202.

León Pinelo, Antonio, Recopilación de las Indias, México, Porrúa, 1992 [1681], 3 tomos.

López Caballero, Paula (comp.), Los títulos primordiales del centro de México, México, Consejo Nacional Para la Cultura y las Artes, 2003.

López Castillo, Gilberto, Composición de tierras y tendencias de poblamiento hispano en la franja costera: Culiacán y Chiametla, siglos XVII y XVIII, Guadalajara, 
Instituto Nacional de Antropología e Historia/Centro INAH Sinaloa/H. Ayuntamiento de Culiacán/Instituto Municipal de Cultura, 2014.

Mendoza García, J. Édgar, "Las composiciones de tierras en la Mixteca y la formación del territorio comunal de cabeceras y sujetos, siglo XVIII", Manuel A. Hermann Lejarazu (coord.), Configuraciones territoriales en la Mixteca, Vol. 1. Estudios de historia y antropología, México, Centro de Investigaciones y Estudios Superiores en Antropología Social, 2015: 255-281.

Menegus, Margarita, "La costumbre indígena en el Derecho Indiano, 1529-1550", Anuario Mexicano de la Historia del Derecho, 4 (México, 1992): 151-159.

Menegus, Margarita, "Los títulos primordiales de los pueblos de indios", Margarita Menegus Bornemann (coord.), Dos décadas de investigación en historia económica comparada en América Latina. Homenaje a Carlos Sempat Assadourian, México, El Colegio de México, Centro de Investigaciones y Estudios Superiores en Antropología Social, Instituto Doctor José María Luis Mora/Centro de Estudios Sobre la Universidad/UNAM, 1999: 137-161.

Menegus, Margarita, "Del usufructo, de la posesión y de la propiedad: las composiciones de tierras en la Mixteca, Oaxaca", Itinerarios, 25 (Varsovia, 2017): 193-208.

Noguez, Xavier y Wood, Stephanie (coords.), De Tlacuilos y escribanos. Estudios sobre documentos indígenas coloniales del centro de México, Zamora, El Colegio de Michoacán/El Colegio Mexiquense, 1998.

Pérez Zevallos, Juan Manuel, "Las reubicaciones tempranas de México. La reubicación de la población indígena en la Nueva España”, Jesús Manuel Macías Medrano (coord.), Investigación evaluativa de reubicaciones humanas por desastres en México, México, Secretaría de Desarrollo Social, Consejo Nacional de Ciencia y Tecnología, 2009: 19-48.

Peset, Mariano y Menegus, Margarita, "Rey soberano o rey propietario", Historia Mexicana, XLIII-4/172 (México, abril-junio 1994): 563-598.

Prem, Hanns J., Milpa y hacienda. Tenencia de la tierra indígena y española en la cuenca del Alto Atoyac, Puebla, México (1520-1650), Puebla, Centro de investigaciones y Estudios Superiores en Antropología Social/Fondo de Cultura Económica/Gobierno del Estado de Puebla, 1988.

Ruiz Medrano, Ethelia, Mexico's Indigenous Communities. Their Lands and Histories, 1500-2010, Colorado, University Press of Colorado, 2010.

Sánchez Mejía, Hugues Rafael, “Composición, mercedes de tierras realengas y expansión ganadera en una zona de frontera de la gobernación de Santa Marta: Valledupar (1700-1810)", Anuario colombiano de historia social y de la cultura, 39/1 (Bogotá, enero-junio 2012): 81-117.

Solano, Francisco de, Tierra y sociedad en el reino de Guatemala, Guatemala, Universidad de San Carlos de Guatemala, 1977. 
Solano, Francisco de, "El juez de tierras y la Superintendencia del Beneficio y Composición de Tierras", Anuario Histórico Jurídico Ecuatoriano, separata, VI (Quito, 1980): $347-358$.

Solano, Francisco de, Cedulario de Tierras. Compilación de legislación agraria colonial (1497-1820), México, Universidad Nacional Autónoma de México, Instituto de Investigaciones Jurídicas, 1984.

Te Paske, John y Hernández Palomo, Mari Luz, La Real Hacienda de Nueva España. La Real Caja de México (1576-1816), México, Instituto Nacional de Antropología e Historia, 1976.

Torales Pacheco, María Cristina, Tierras de indios, tierras de españoles. Confirmación y composición de tierras y aguas en la jurisdicción de Cholula (siglos XVI-XVIII), México, Universidad Iberoamericana, 2005.

Torre Ruiz, Rosa Alicia de la, "Composiciones de tierras en la alcaldía mayor de Sayula, 1692-1754: un estudio de caso sobre el funcionamiento del Juzgado Privativo de Tierras", Letras históricas, 6 (Guadalajara, primavera-verano 2012): 45-69.

Wobeser, Gisela von, La formación de la hacienda en la época colonial. El uso de la tierra y el agua, México, Universidad Nacional Autónoma de México, 1989.

Fecha de recepción: 11 de mayo de 2017.

Fecha de envío de las modificaciones: 5 de agosto de 2017.

Fecha de aceptación: 28 de agosto de 2017.

\section{The foundation of the Juzgado Privativo de Tierras y Aguas of the Real Audiencia de México, 1692-1735}

This article analyses the legal provisions promulgated by Spanish kings that led to the founding of government agencies commissioned for the regularization of land ownership in colonial America between the seventeenth and eighteenth centuries. The decrees and edicts of the ministers of the Juzgado Privativo de Tierras de la Real Audiencia de México are published to analyse the operation of this government unit and the activities of its commissioners in the New Spain jurisdictions. Likewise, the importance for Mexico's rural history of the "composiciones" and sales of vacant land is underlined, as these were procedures that helped consolidate the right to absolute property and affected the communal property of the "pueblos de indios" and their territorial configuration.

KeY words: Agrarian Regularization; Juzgado Privativo de Tierras; New Spain; composiciones of Indian lands. 